\title{
A SECULARIZAÇÃO DO BRASIL: autonomização, pluralização e privatização da religião
}

\section{Gilson Ciarallo}

Curso: Doutorado em Sociologia

Data de defesa da tese: 11 de março de 2005

Orientador: Prof. Dr. Caetano Ernesto Pereira de Araújo

\section{Resumo}

O cenário religioso brasileiro atual tem despertado interpretações contrastantes nos quadros das ciências sociais, por vezes colocando em dúvida não só o processo de secularização como também os atributos dele decorrentes. Os esforços reunidos nesta tese têm como desígnio contribuir para elucidar o tema através de um estudo histórico da secularização do Brasil. Visando a alcançar tal desígnio, faz-se um estudo da secularização buscando seus sentidos originais, bem como aqueles outros que se foram adicionando no desenvolvimento das ciências sociais.

Levando em conta uma visão analítica tríplice, eventos e circunstâncias históricas são compreendidos a partir de três processos, todos eles entendidos como secularização em níveis de análise distintos: o processo de autonomização das esferas em relação à religião, no nível de análise macro; o processo de pluralização da religião, no nível de análise meso; e o processo de privatização da religião, no nível de análise micro. $\mathrm{O}$ primeiro destes processos é analisado considerando-se a autonomização do Estado, da educação e do direito, processos estes que se efetuam no Brasil em circunstâncias e momentos decisivos. O segundo, através de um olhar para as transformações da esfera religiosa brasileira, a qual se diversifica e toma as formas de um "mercado religioso" competitivo. 
O terceiro processo é examinado considerando-se o advento, no Brasil, da religião como assunto da esfera privada, num contexto de grande mobilização religiosa, pertencimentos múltiplos e variadas composições religiosas individuais.

A observação desses processos ao longo da história conduz à compreensão da secularização do Brasil como processo decisivo e efetivado. Outrossim, os aspectos que levam os cientistas sociais a hesitar na atribuição do caráter secularizado à sociedade brasileira são os mesmos que atestam vigorosamente a plena efetivação da secularização.

Palavras-chave: Brasil, secularização, religião e sociedade, História da Igreja. 